\title{
Recrudescence of Helicobacter pylori after apparently successful eradication: novel application of randomly amplified polymorphic DNA fingerprinting
}

\author{
H X Xia, H J Windle, D G Marshall, C J Smyth, C T Keane, C A O'Morain
}

\begin{abstract}
The aim of this study was to find out if reinfection or recrudescence accounted for the recurrence of Helicobacter pylori infections after apparent eradication of the bacterium. Three hundred and twenty patients were treated with colloidal bismuth subcitrate $(120 \mathrm{mg}$ four times daily for four weeks), metronidazole and tetracycline (400 $\mathrm{mg}$ and $500 \mathrm{mg}$, respectively, thrice daily for the first week). H pylori was eradicated four weeks after the end of treatment as assessed by the rapid urease test, histological examination, Gram staining, and culture. However, the infection recurred in $29(9.1 \%)$ of the patients one year after apparent eradication. Pre and posteradication isolates from five patients were available. DNA was extracted and used for restriction endonuclease analysis with Hind III and Hae III, and for polymerase chain reaction (PCR) based randomly amplified polymorphic DNA fingerprinting with a combination of two 10 nucleotide primers. Sodium dodecyl sulphate polyacrylamide gel electrophoretic analysis was performed also. Randomly amplified polymorphic DNA fingerprinting was unique in that it yielded highly discriminatory fingerprints, which showed that the pretreatment and recurrent isolates obtained from each of the five patients were indistinguishable from one another. This shows that recurrence of $H$ pylori infection is probably caused by recrudescence and that the discriminatory power of randomly amplified polymorphic DNA fingerprinting is a practicable and discriminatory typing scheme for $H$ pylori.

(Gut 1995; 37: 30-34)
\end{abstract}

Keywords: Helicobacter pylori, DNA fingerprinting, recrudescence.

Eradication of Helicobacter pylori cures duodenal ulcer ${ }^{1-3}$ and ulcer complications. ${ }^{45} \mathrm{An}$ eradication rate of $84.3 \%$ is obtained with colloidal bismuth subcitrate $(120 \mathrm{mg}$ four times daily for four weeks), metronidazole and tetracycline $(400 \mathrm{mg}$ and $500 \mathrm{mg}$ thrice daily for the first week, respectively). ${ }^{6}$ However, recurrence of the infection after apparent eradication has been reported and is associated with the ulcer relapse. ${ }^{13}$ 7-9 Recent studies have shown that recurrence of $H$ pylori is dependent on the efficacy of the treatment regimen. The more effective the treatment, the lower the recurrence rate. ${ }^{9} 10 a$ This study was conducted to find out if recurrence of $H$ pylori was caused by reinfection or recrudescence by molecular characterisation of the pretreatment and recurrent isolates from patients, who had been treated with the triple therapy, using three fingerprinting techniques. Sodium dodecyl sulphate polyacrylamide gel electrophoresis (SDS-PAGE) of whole cell proteins, restriction endonuclease analysis (REA) of genomic DNA and polymerase chain reaction (PCR) based random amplified polymorphic DNA (RAPD) fingerprinting technique were used in this analysis.

\section{Methods}

\section{Clinical details of the patients and $\mathrm{H}$ pylori} isolates

Three hundred and twenty Irish patients with confirmed duodenal ulcer were treated with a triple therapy, which included colloidal bismuth subcitrate $(120 \mathrm{mg}$ four times daily for four weeks), metronidazole and tetracycline (400 $\mathrm{mg}$ and $500 \mathrm{mg}$, respectively, thrice daily for the first week). $H$ pylori was eradicated four weeks after the end of treatment as assessed by the rapid urease test (CLO test, Delta West, Perth, Western Australia), histological examination, Gram staining, and culture (all showed negative results for $H$ pylor $)$. Details of specimen preparation and classification criteria for gastritis used in this study have been described elsewhere. ${ }^{1}$ Each of the patients had a routine endoscopy one year after apparent eradication of the bacterium, or sooner if symptoms recurred. Recurrence of $H$ pylori infection was defined as any one (or more) of the four tests described for $H$ pylori being positive. Recurrence of $H$ pylori infection was apparent in $29(9 \cdot 1 \%)$ of the patients. Posteradication $H$ pylori was isolated from antral biopsy specimens of 23 of these patients. Both pretreatment and recurrent isolates were, however, successfully recovered from only five of these patients; two isolates were obtained from each of four patients, and three isolates from one patient. The Table gives the clinical details of these five patients and the 11 isolates. 
Clinical details of the patients before $\mathrm{H}$ pylori was apparently eradicated with colloidal bismuth subcitrate, metronidazole, and tetracycline (triple therapy) and after the infection recurred during a period of follow up

\begin{tabular}{|c|c|c|c|c|c|c|c|}
\hline Patient & $\begin{array}{l}\text { Treatment } \\
\text { status }\end{array}$ & $\begin{array}{l}A g e \\
(y)\end{array}$ & Sex & $\begin{array}{l}\text { Endoscopic } \\
\text { diagnosis }\end{array}$ & $\begin{array}{l}\text { Histological } \\
\text { findings }\end{array}$ & Isolate & $\begin{array}{l}\text { Follow up } \\
\text { (months) }\end{array}$ \\
\hline A & $\begin{array}{l}\text { Before } \\
\text { After }\end{array}$ & 32 & Female & $\begin{array}{l}\text { DU } \\
\text { NUD }\end{array}$ & $\begin{array}{l}\mathrm{Mo}+\mathrm{Ac} \\
\mathrm{Mo}+\mathrm{Ac}\end{array}$ & $\begin{array}{l}\text { A1 } \\
\text { A2 }\end{array}$ & 7 \\
\hline B & $\begin{array}{l}\text { Before } \\
\text { After }\end{array}$ & 60 & Female & $\begin{array}{l}\text { DU } \\
\text { DU }\end{array}$ & $\underset{\mathrm{Mi}}{\mathrm{Mi}}+\mathrm{Ac}$ & $\begin{array}{l}\text { B1 } \\
\text { B2 }\end{array}$ & 8 \\
\hline $\mathrm{C}$ & $\begin{array}{l}\text { Before } \\
\text { After }\end{array}$ & 19 & Female & $\begin{array}{l}\text { DU } \\
\text { NUD }\end{array}$ & $\begin{array}{l}\mathrm{Mo}+\mathrm{Ac} \\
\mathrm{Mi}+\mathrm{Ac}\end{array}$ & $\begin{array}{l}\text { C1 } \\
\text { C2 }\end{array}$ & 10 \\
\hline D & $\begin{array}{l}\text { Before } \\
\text { After } \\
\text { After }\end{array}$ & 31 & Male & $\begin{array}{l}\text { DU } \\
\text { DU } \\
\text { DU }\end{array}$ & $\begin{array}{l}\mathrm{Ma}+\mathrm{Ac} \\
\mathrm{Ma}+\mathrm{Ac} \\
\mathrm{Ma}+\mathrm{Ac}\end{array}$ & $\begin{array}{l}\text { D1 } \\
\text { D2a } \\
\text { D2b }\end{array}$ & 12 \\
\hline E & $\begin{array}{l}\text { Before } \\
\text { After }\end{array}$ & 66 & Female & $\begin{array}{l}\text { DU } \\
\text { NUD }\end{array}$ & $\begin{array}{l}\mathrm{Mo}+\mathrm{Ac} \\
\mathrm{Mo}+\mathrm{Ac}\end{array}$ & $\begin{array}{l}\text { E1 } \\
\text { E2 }\end{array}$ & $22^{\star}$ \\
\hline
\end{tabular}

${ }^{\star} H$ pylori was positive 13 months after eradication, but only cultured nine months later; DU, duodenal ulcer; NUD, non-ulcer dyspepsia; $\mathrm{Mi}+\mathrm{Ac}$, mild and active antral gastritis; Mo + Ac, moderate and active antral gastritis; $\mathrm{Ma}+\mathrm{Ac}$, considerable and active antral gastritis.

Preparation of bacterial cells

Pre and posteradication isolates of $H$ pylori from patients $A, B, C$ were used for REA, and from patients $A, B, C$, and $D$ for SDS-PAGE. All the isolates were used for RAPD. A reference $H$ pylori strain NCTC 11638 was included in all but one of the experiments. Each isolate was recovered from tryptone soya broth containing glycerol $(20 \%, \mathrm{v} / \mathrm{v})$ and horse serum $(10 \%, \mathrm{v} / \mathrm{v})$ and stored at $-70^{\circ} \mathrm{C}$. The recovered isolates were then subcultured either on chocolate agar plates for three to five days in a microaerophilic atmosphere at $37^{\circ} \mathrm{C}$, or in a tissue culture flask containing brain heart infusion broth $(20 \mathrm{ml})$ containing horse serum $(5 \%, v / v)$ and yeast extract $(0.25 \%, w / v)$ for 24-48 hours, exactly as described previously. ${ }^{10}$

\section{SDS-PAGE}

Agar grown bacteria were harvested with phosphate buffered saline (PBS, $\mathrm{pH} 7 \cdot 3$ ) and washed twice in this buffer prior to measuring the protein content of each strain by the method of Markwell et al. ${ }^{11}$ Bacterial protein $(10 \mu \mathrm{g})$ in PBS was precipitated by the addition of five volumes of ice cold acetone, followed by incubation at $-20^{\circ} \mathrm{C}$ for 30 minutes. After washing the precipitate once with acetone, the pellet was resuspended in $10 \mu \mathrm{l}$ sample buffer. The mixture was boiled for four minutes prior to electrophoresis. SDS-PAGE was performed as previously described, ${ }^{12}$ using $12.5 \%$ acrylamide resolving gels. Molecular weight markers were SDS-PAGE broad range standards (Bio-Rad, CA, USA).

\section{Extraction of genomic DNA}

Bacterial cells on chocolate agar (two plates), or liquid medium $(15 \mathrm{ml})$ were washed with PBS (pH 7.,3) and $25 \mathrm{mM}$ TRIS-HCl buffer (pH 8.0) containing $10 \mathrm{mM}$ EDTA. The suspension was transferred into an Eppendorf tube and washed twice with TRIS-HCl buffer. DNA was extracted by a phenol/chloroform method similar to the method previously described. ${ }^{13}$ Briefly, the pellet of cells was resuspended in $0.5 \mathrm{ml}$ lysis buffer $(25 \mathrm{mM}$ TRIS- $\mathrm{HCl}(\mathrm{pH} \mathrm{8.0)}, 50 \mathrm{mM}$ glucose, $10 \mathrm{mM}$ EDTA, lysozyme $(30 \mathrm{mg} / \mathrm{ml}))$ and incubated at room temperature for 15 minutes. The suspension was treated with SDS, RNase A, and then pronase. DNA was extracted with phenol/chloroform/isoamyl alcohol, precipitated by sodium acetate and cold absolute alcohol, and washed with ice cold alcohol $(70 \%$, v/v). The pellet of DNA was finally resuspended in $10 \mathrm{mM}$ TRIS-HCl buffer ( $\mathrm{pH}$ $7 \cdot 5)$ containing $1 \mathrm{mM}$ EDTA. DNA content and purity was determined by measuring the absorbance at $260 \mathrm{~nm}$ and $280 \mathrm{~nm}$ using a spectrophotometer (Hitachi, U-2000, Japan). All reagents used for DNA extraction were obtained from Sigma Chemical, MO, USA. DNA templates for RAPD were prepared also by the boiling method exactly as described by Mazurier et al. ${ }^{14}$

\section{REA and RAPD}

Restriction endonuclease digestion of $H$ pylori genomic DNA with Hind III or Hae III was carried out according to the manufacturer's instructions (Boehringer Mannheim, $\mathrm{GmbH}$, Germany).

RAPD fingerprinting was carried out in a final volume of $25 \mu \mathrm{l}$ containing $3 \mathrm{mM} \mathrm{MgCl} \mathrm{Mg}_{2}$, 20 pmol of each primer, $2.5 \mathrm{U}$ of Taq DNA polymerase (Promega, WI, USA), $250 \mu \mathrm{M}$ each of dCTP, dGTP, dATP, dTTP (Boehringer Mannheim) in $10 \mathrm{mM}$ TRIS- $\mathrm{HCl}$ (pH 8.3) containing $50 \mathrm{mM} \mathrm{KCl}$ and Triton $\mathrm{X}-100(1 \%, \mathrm{v} / \mathrm{v})$. The mixture was overlaid with mineral oil and exposed to ultraviolet radiation for 10 minutes. Between 5 and 500 ng DNA template of each isolate obtained by the phenol/chloroform method, or $5 \mu l$ cell supernatant fraction prepared by the boiling method was used for PCR. The primers used were a combination of two 10 nucleotide primers, primer 1281 (AACGCGCAAC) and primer 1283 (GCGATCCCCA) obtained from the Molecular Medicine Unit, King's College School of Medicine and Dentistry, London. The synthesis and specificity of these primers has been described previously. ${ }^{1516} \mathrm{~A}$ Perkin-Elmer TC480 thermal cycler (Cetus, USA) was used for amplification. The cycling programme was four cycles of $\left(94^{\circ} \mathrm{C}, 5 \mathrm{~min}\right.$; $36^{\circ} \mathrm{C}, 5 \mathrm{~min}$; and $\left.72^{\circ} \mathrm{C}, 5 \mathrm{~min}\right), 30$ cycles of $\left(94^{\circ} \mathrm{C}, 1 \mathrm{~min} ; 36^{\circ} \mathrm{C}, 1 \mathrm{~min}\right.$; and $\left.72^{\circ} \mathrm{C}, 2 \mathrm{~min}\right)$, and then $72^{\circ} \mathrm{C}$ for 10 minutes.

\section{Agarose gel electrophoresis}

Genomic DNA $(20 \mu \mathrm{l})$ or digested DNA $(20 \mu \mathrm{l})$ was mixed with $5 \mu \mathrm{l}$ loading buffer consisting of $50 \%(\mathrm{v} / \mathrm{v})$ TBE running buffer (pH 8.0), glycerol $(50 \%, v / v)$, and bromophenol blue $(0 \cdot 25 \%$, w/v). Loading buffer ( 5 $\mu \mathrm{l}$ ) was added to an aliquot of PCR products and $20 \mu \mathrm{l}$ of the mixture was electrophoresed. A $0.5 \%$ agarose gel was used for genomic DNA, a $0.8 \%$ agarose gel for digested DNA, and a $2 \%$ agarose gel for PCR products. After electrophoresis in $0.5 \times \mathrm{TBE}$ buffer at $70 \mathrm{~V}$, gels were stained in ethidium bromide $(0.5 \mathrm{mg} / \mathrm{ml})$ and photographed under ultraviolet light. Hind III digested bacteriophage $\lambda$ DNA (Sigma) was used as a size marker for genomic DNA in REA; a 100 bp DNA ladder (Gibco, BRL) was used for PCR products. 


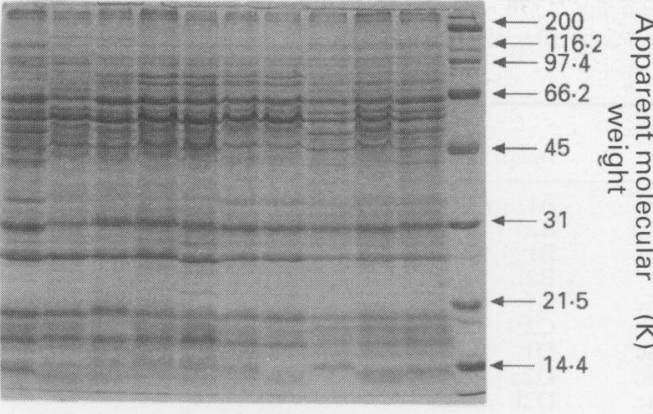

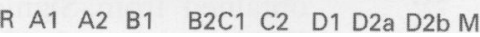

Figure 1: SDS-PAGE protein profiles of reference strain NCTC $11638(R)$ and paired clinical isolates from patients $A, B, C$, and $D$. The molecular weight marker proteins (M) were myosin $(M r=200000), \beta$-galactosidase $(M r=116250)$, phosphorylase $b(M r=97400)$, bovine serum albumin $(M r=66200)$, ovalbumen $(M r=45000)$ carbonic anhydrase $(M r=31000)$, soya bean trypsin inhibitor $(M r=21500)$, and lysozyme $(M r=14400)$.

\section{Results}

\section{SDS-PAGE}

Patterns of whole cell protein extracts obtained by SDS-PAGE showed 30-40 bands for each isolate with molecular weights of 20 to $120 \mathrm{~K}$. The six major bands of $27,30,46,54,57$, and $64 \mathrm{~K}$ were present in the protein profiles of all of the isolates. Although the protein patterns of pretreatment and recurrent isolates from individual patients were very similar it was still possible to distinguish between the profiles of paired isolates from different patients because of minor variations in the expression of some protein constituents, chiefly in the $100-200 \mathrm{~K}$ and the $30-37 \mathrm{~K}$ regions (Fig 1 ).

\section{REA}

Electrophoresis of undigested genomic DNA showed that the reference strain NCTC 11683 harboured one plasmid of $9.0 \mathrm{~kb}$. Isolates $\mathrm{Al}$ and $\mathrm{A} 2$ both harboured two plasmids of the same size ( $9.6 \mathrm{~kb}$ and $5.4 \mathrm{~kb})$. C1 and C2 both had two plasmids of the same size also $(15 \mathrm{~kb}$

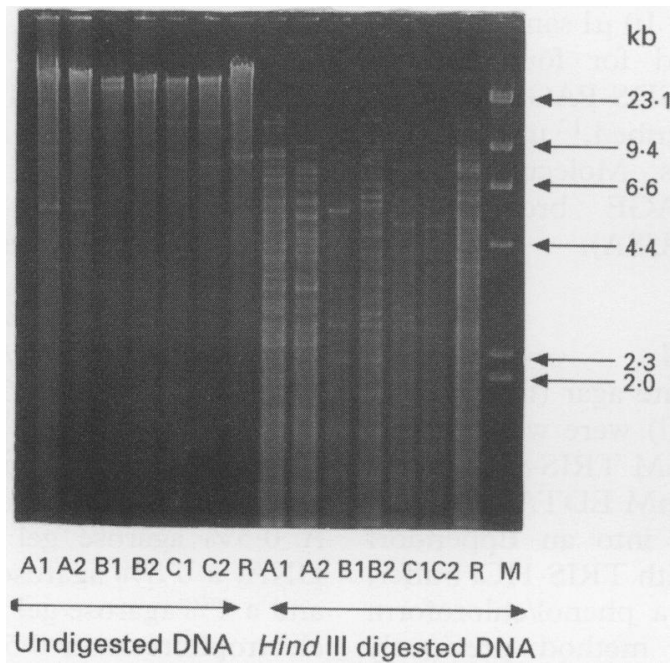

Figure 2: Restriction endonuclease analysis. Agarose gel electrophoretic patterns of undigested genomic DNA (left hand side) and Hind III digested DNA (right hand side) restriction fragments of strain NCTC $11638(R)$ and paired isolates from patients $A, B$, and $C$. The molecular size markers $(M)$ are fragments from Hind III digested bacteriophage $\lambda D N A$. and $8 \cdot 2 \mathrm{~kb}$ ). Isolates $\mathrm{B} 1$ and $\mathrm{B} 2$ shared one plasmid of $25 \mathrm{~kb}$ (Fig 2). Hind III digested DNA from all of the three pairs of isolates (Figs 2 and 3), but $\mathrm{Hae}$ III only cut DNA from isolate B (Fig 3). Hind III digest profiles of genomic DNA from isolates $\mathrm{C} 1$ and $\mathrm{C} 2$ were very similar (Fig 3), whereas the REA profiles of isolates $\mathrm{A} 1$ and $\mathrm{A} 2$ and of isolates $\mathrm{B} 1$ and $\mathrm{B} 2$ showed considerable similarity, although a number of band differences were apparent in the $8-10 \mathrm{~kb}$ regions of the isolates A1/A2 and in the $6-6.5 \mathrm{~kb}$ region of the paired isolates B1/B2 (Figs 2 and 3). There were distinct differences in the digest profiles of DNA between the clinical isolates, and between the clinical isolates and the reference strain.

\section{$R A P D$}

RAPD fingerprinting with a combination of the two 10 nucleotide primers yielded 10 to 20 main bands on the agarose gels. The profiles of the PCR products from the DNA of the paired isolates $\mathrm{A} 1 / \mathrm{A} 2, \mathrm{~B} 1 / \mathrm{B} 2, \mathrm{C} 1 / \mathrm{C} 2, \mathrm{D} 1-\mathrm{D} 2 \mathrm{a} / \mathrm{D} 2 \mathrm{~b}$, and $\mathrm{E} 1 / \mathrm{E} 2$ were clearly indistinguishable from one another when the DNA was prepared by the phenol/chloroform method (Fig 4, data for E1/E2 not shown). However, isolates from patients $\mathrm{A}, \mathrm{B}, \mathrm{C}, \mathrm{D}, \mathrm{E}$, and the reference strain yielded considerably different RAPD profiles. The DNA templates prepared by the boiling method also yielded highly discriminatory fingerprints, although slightly less PCR products were obtained when compared with the DNA templates prepared by the phenol/ chloroform method (Fig 5).

\section{Discussion}

In this study we have shown that the DNA fingerprints of five paired pretreatment and recurrent $H$ pylori isolates from five patients were identical. This was accomplished by the application of RAPD fingerprinting to confirm the identity of the paired isolates. Our findings clearly showed that recrudescence, rather than reinfection, accounted for the recurrence of

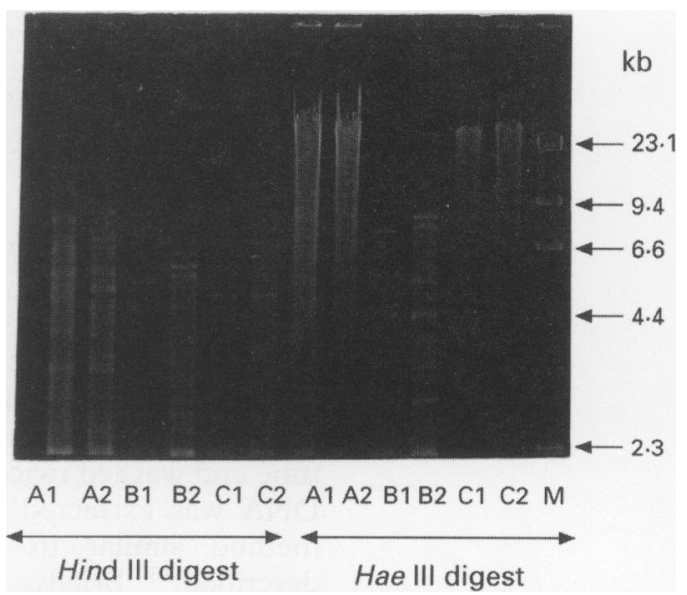

Figure 3: Restriction endonuclease analysis. Agarose gel electrophoretic patterns of Hind III digested (left hand side) and $\mathrm{Hae}$ III digested (right hand side) DNA restriction fragments of paired isolates of $\mathrm{H}$ pylori from patients $A, B$, and $C$. The molecular size markers (M) are fragments from $\mathrm{Hin}$ III digested bacteriophage $\lambda D N A$. 


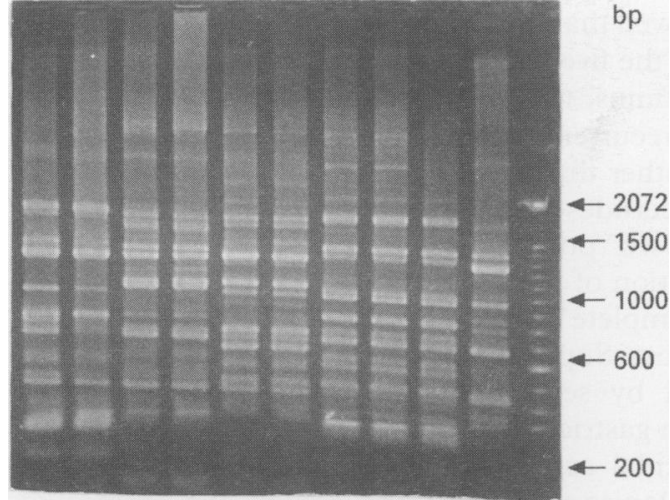

A1 A2 B1 B2 C1 C2 D1 D2a D2b R M

Figure 4: Representative agarose gel electrophoretic patterns of RAPD products of genomic DNA of reference strain NCTC $11638(R)$ and paired isolates from patients $A, B$, $C$, and $D . M=$ size markers, 100 base pair ladder.

$H$ pylori infection after apparent eradication with antimicrobial therapy in all five cases examined. Both SDS-PAGE and REA had less discriminatory power when compared with RAPD. To our knowledge, this is the first reported application of RAPD to confirm the identity of paired clinical isolates of $H$ pylori obtained from subjects in whom recurrence of the infection occurred after apparent eradication of the organism. The discriminatory power of RAPD fingerprinting represents a potentially practicable and discriminatory typing scheme for $H$ pylori.

Several fingerprinting techniques have been used for typing $H$ pylori. The numerical analysis of SDS-PAGE protein patterns ${ }^{17}$ and restriction endonuclease DNA analysis ${ }^{13} 1819$ are sensitive and useful for defining the similarities between isolates. Both techniques are time consuming, however, and scanning the numerous bands for each pattern requires expensive equipment. Ribotyping with Hae III and Hind III provides a reliable, reproducible, and discriminatory basis for distinguishing one strain from another. ${ }^{2021}$ However, the DNA of $25 \%$ of strains is not cut by Hae III. Hind III ribotyping patterns are conserved, with several groups of $H$ pylori often having the same ribopattern. ${ }^{21}$ In this study, DNA from two of three pairs of strains were not cut by Hae III.

PCR based RAPD fingerprinting is a recently developed technique. ${ }^{22}$ Its simplicity, versatility, and economy make it an ideal means of genetically fingerprinting isolates. This technique has been used successfully to distinguish clinical isolates of $H$ pylori ${ }^{15}$ and a combination of the two 10 nucleotide primers used in this study, 1281 and 1283, was found previously to be very suitable for discriminating Irish isolates. ${ }^{16}$ In this study, SDS-PAGE protein profiling and restriction endonuclease DNA fingerprinting analysis were applied also, but the electrophoretic patterns were not as easy to compare. In our hands REA yielded less informative data than RAPD. It is interesting to note that other workers using REA found both minor and major band differences between many paired isolates. ${ }^{13}$ However, the reasons for the reproducible differences we saw when using REA are not clear. In any event,
RAPD yielded very satisfactory fingerprinting profiles. Ready discrimination between the isolates was possible even when the DNA template was prepared by a boiling method.

Recurrence rates of $H$ pylori infection from $0-50 \%$ have been reported for patients who are followed up for periods of one to seven years. ${ }^{1-3} 7-9$ Recurrence rates differ depending on the treatment regimen. ${ }^{9}$ We have shown that of 125 one year follow up patients, in whom $H$ pylori had been eradicated, the infection recurred in $47.1 \%$ of the patients treated with monotherapy, in $31.8 \%$ of those treated with dual therapy, and in $10.9 \%$ of those treated with triple therapy. ${ }^{10 a}$ Therefore, the more effective treatment is associated with a low recurrence rate. Furthermore, in a clinical study of 304 patients, who were followed up trimonthly for 60 months, ${ }^{9} 19(6 \cdot 3 \%)$ had $H$ pylori recurrence as assessed using a single test, the ${ }^{14} \mathrm{C}$ urea breath test; 17 of which $(89.5 \%$ of the 19 recurrences) occurred within six months after treatment (11 within three months). None of the patients were 'reinfected' with the organism after 24 months. A higher recurrence rate $(9 \cdot 1 \%)$ was seen in this study, using four techniques to detect $H$ pylori. Although the recurrent isolates from the five patients were cultured between seven and 22 months after the first isolation in this study, the infection might have recurred much earlier as two of these patients did not present until symptoms returned and the other three attended for a one year follow up endoscopy without symptoms.

Previous studies, using SDS-PAGE and REA, have shown that strains of $H$ pylori from different patients are genetically distinct from each other, and that the same strains persist in patients for at least two years, even after the patients received antimicrobial therapy. ${ }^{17} 18$ Langenberg et al have also shown that a recurrent strain of $H$ pylori, after apparently successful eradication is genetically identical to the pretreatment strain using REA. ${ }^{18}$ In our study, the five patients examined were from 29 patients in whom $H$ pylori infection recurred after apparently successful eradication. They were selected only on the basis that both their pre and posteradication isolates were available. Thus, these five patients were possibly representative of all the 29 patients. DNA

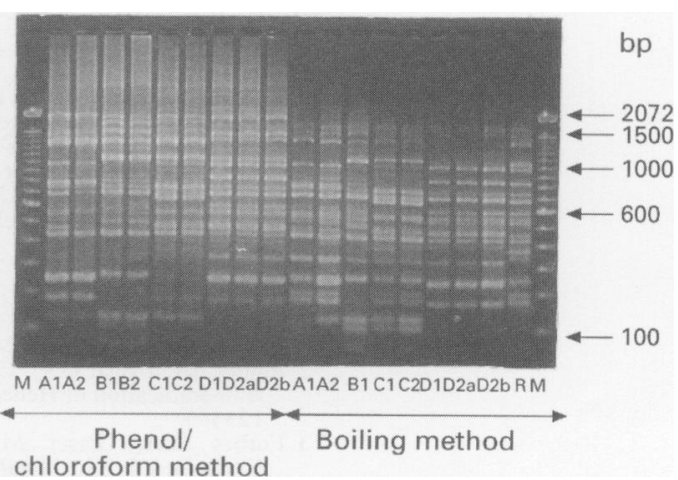

Figure 5: Representative agarose gel electrophoretic pattern of $R A P D$ products of genomic DNA of $\mathrm{H}$ pylori prepared by the phenol/chloroform (left hand side) and boiling (right hand side) methods. $R=$ reference strain NCTC 11638 $M=$ size markers, 100 base pair ladder. 
fingerprints of RAPD showed that the recurrent $H$ pylori strains in each of the five patients were identical to the original strains, which suggests that the nature of $H$ pylori recurrence after eradication is recrudescence rather than reinfection.

The means by which recrudescence arises is equivocal at present. Two possibilities are either incomplete eradication of the bacterium by drug treatment or incomplete elimination of the bacterium from the host. Support for these explanations is provided by several studies. $H$ pylori can live in human gastric pits, where it might avoid the bactericidal activity of antimicrobial agents and recolonise after treatment has finished. ${ }^{23} \mathrm{H}$ pylori can also change its morphology from typical helical to a coccoidal form under the hostile conditions found in the gastric environment and can revert to its original shape under favourable conditions. ${ }^{24}$ Incomplete elimination would most probably occur if the organism inhabited a reservoir other than the stomach. This possibility is strengthened by the findings that $H$ pylori has been found in saliva, ${ }^{25}$ dental plaque, ${ }^{26}$ and faeces. ${ }^{27} 28$ In addition, as it has been found that members within the same family may harbour identical strains, ${ }^{2029}$ there is also a possibility that these patients might have been reinfected with strains from the same reservoir as the pretreatment strains. Other studies, however, have shown that most family members are infected with different strains. ${ }^{13} 19$

In conclusion, the findings in this study using a highly discriminatory molecular fingerprinting technique, RAPD, show that the recurrence of $H$ pylori infection after apparently successful eradication is caused by recrudescence rather than reinfection. Thus, the definition of eradication of $H$ pylori currently used may need to be revised. It is suggested that eradication should be defined as the inability to detect $H$ pylori at least six months after cessation of antimicrobial therapy. ${ }^{9}$ Furthermore, as $H$ pylori urease activity may be undetectable in small numbers of organisms ${ }^{30}$ or when expression of the enzyme is inhibited by antimicrobial agents or proton pump inhibitors for a period of time after treatment, ${ }^{31}$ tests that are based on urease activity should be complemented by at least one other technique, such as Gram staining, culture, histological examination or serology when determining the extent of eradication or recurrence of $H$ pylori infection.

The preliminary results of this study were orally presented to the British Society of Gastroenterology in March 1994. (Gut 1994 35 (suppl 2): S3.) The authors thank the medical and endoscop staff and research nurses of Meath/Adelaide Hospitals and Professor Jinkun Zhang of Union Hospital, Wuhan, Peoples Republic of China, for their help, cooperation, and support.

1 Patchett S, Beattie S, Leen E, Keane C, O'Morain C. Helicobacter pylori and duodenal ulcer recurrence. $A n \mathscr{f}$ Gastroenterol 1992; 87: 24-7.

2 Rauws EA, Tytgat GNJ. Cure of duodenal ulcer associated with eradication of Helicobacter pylori. Lancet 1990; 335: 1233-5.

3 Forbes GM, Glaser ME, Cullen DJE, Warren JR, Christiansen KJ, Marshall BJ, et al. Duodenal ulcer treated with Helicobacter pylori eradication: seven-yea ollow-up. Lancet 1994; 343: 258-60.

4 Graham DY, Hepps KS, Ramirez FC, Lew GM, Saeed ZA Treatment of Helicobacter pylori reduces the rebleedin in peptic ulcer disease. Scand $\mathcal{F}$ Gastroenterol 1993; 28: 939-42.
5 Labenz J, Borsch G. Role of Helicobacter pylori eradication in the prevention of peptic ulcer bleeding relapse. Digestion 1994; 55: 19-23.

6 Xia HX, Daw MA, Sant S, Beattie S, Keane CT, O'Morain CA. Clinical efficacy of triple therapy in Helicobacter pylori-associated duodenal ulcer. European fournal of pylori-associated duodenal ulcer. European Gastroenterology and Hepatology 1993; 5: 141-4.

7 Borody T, Andrews P, Mancuso N, Jankiewicz E, Brandl S. Helicobacter pylori reinfection 4 years post-treatment. Lancet 1992; 339: 1295 .

8 Labenz J, Gyenes E, Ruhl GH, Borsch G. Helicobacter pylori re-infection and clinical course of peptic ulcer disease in the first year post-amoxicillin/omeprazole treatment. European fournal of Gastroenterology and Hepatology 1992; 4: 493-6.

9 Bell GD, Powell KU, Burridge SM, Harrison G, Rameh B, Weil J, et al. Reinfection or recrudescence after apparently successful eradication of Helicobacter pylori infection implications for treatment of patients with duodenal ulcer disease. $Q \Im$ Med 1993; 86: 375-82.

10a Xia HX, Gilvarry J, Sweeney EC, Beattie S, Hamilton $H$ Keane CT, et al. Recrudescence of Helicobacter pylori infection in patients with healed duodenal ulcer after treatment with different regimens. Am $\mathcal{F}$ Gastroenterol (in press).

10 Xia HX, English L, Keane CT, O'Morain CA. Enhanced cultivation of Helicobacter pylori in liquid media. $\mathcal{f}$ Clin Pathol 1993; 46: 750-3.

11 Markwell MAK, Haas SM, Bieberg LL, Tolbert NE. A modification of the Lowry procedure to simplify protein determination in membrane and lipoprotein samples. Anal Biochem 1978; 87: 206-10.

12 Laemmli UK. Cleavage of structural proteins during the assembly of the head of bacteriophage T4. Nature 1970; 227: $680-5$.

13 Majewski SI, Goodwin CS. Restriction endonuclease analysis of the genome of Campylobacter pylori with rapid extraction method: evidence for considerable genomic variation. F Infect Dis 1988; 157: 465-71.

14 Mazurier S, van de Giessen A, Heuvelman K, Wernars $K$ RAPD analysis of Campylobacter isolates: DNA fingerprinting without the need to purify DNA. Lett Appl Microbiol 1992; 14: 260-2.

15 Akopyanz N, Bukanov NO, Westblom TU, Kresovich S, Berg DE. DNA diversity among clinical isolates of Helicobacter pylori detected by PCR based RAPD fingerprinting. Nucleic Acids Res 1992; 20: 5137-42.

16 Marshall DG, Chua A, Keeling PWN, Sullivan DJ, Coleman D, Smyth CJ. Molecular epidemiology of Helicobacter pylori isolates from gastric biopsies. Ir $尹$ Med Sci 1993; 162: 514 .

17 Costas M, Owen RJ, Bickley J, Morgan DR. Molecular techniques for studying the epidemiology of infection by Helicobacter pylori. Scand $\mathcal{F}$ Gastroenterol 1991; 26 (supp 181): 20-32.

18 Langenberg W, Rauws EAJ, Widjojokusumo A, Tytgat GNJ, Zanen HC. Identification of Campylobacter pyloridis isolates by restriction endonuclease DNA analysis. F Clin Microbiol 1986; 24: 414-7.

19 Simor AE, Shames B, Drumm B, Sherman P, Low DE Penner JL. Typing of Campylobacter pylori by bacterial DNA restriction endonuclease analysis and determination of plasmid profile. 7 Clin Microbiol 1990; 28: 83-6.

20 Tee W, Lambert J, Smallwood R, Schembri M, Ross BC Dwyer B. Ribotyping of Helicobacter pylori from clinica specimens. F Clin Microbiol 1992; 30: 1562-7.

21 Owen RJ. Microbiological aspects of Helicobacter pylori infection. Communicable Disease Report Review 1993; 3 R51-6.

22 Welsh J, McClelland $M$. Fingerprinting genomes using PCR with arbitrary primers. Nucleic Acids Res 1990; 18: 7213-8.

23 Goodwin, Armstrong JA, Marshall BJ. Campylobacter pylori, gastritis and peptic ulcer. $\mathcal{f}$ Clin Pathol 1986; 39: 353-65.

24 Mai U, Geis G, Leying H, Ruhl G, Opferkuch W. Dimorphism of Campylobacter pylori. In: Megraud F, Lamouliatte $\mathrm{H}$, eds. Gastroduodenal pathology and Campylobacter pylori. Amsterdam: Elsevier Science, 1989: 29-33.

25 Husson MO, Gottrand F, Turck D, Leclerc H. Detection of Helicobacter pylori in saliva using a monoclonal antibody. Int $\mathcal{f}$ Med Microbiol Virol Parasitol Infect Dis 1993; 279, $466-471$.

26 Takagi A, Ohta U, Kohda K, Kobayashi H, Shirari T Harasawa $S$, et al. Detection of Helicobacter pylori DNA in dental plaque by PCR [Abstract]. Am $\mathcal{f}$ Gastroenterol 1994; 89: 1298.

27 Thomas JE, Gibson GR, Darboe MK, Dale A, Weaver LT Isolation of Helicobacter pylori from human faeces. Lancet 1992; 340: 1194-5.

28 Kelly SM, Pitcher MC, Farmery SM, Gibson GR. Isolation of Helicobacter pylori in faeces from patients in the UKconfirmation of culture identity by PCR [Abstract]. Gut confirmation of culture

29 Rauws EAJ, Langenberg W, Oudbier J, Mulder CJ, Tytgat GNJ. Familial clustering of peptic ulcer disease colonized with C pylori of the same DNA composition Gastroenterology 1989; 96: A409.

30 Xia HX, Keane CT, O'Morain CA. Pre-formed urease activity of Helicobacter pylori as determined by a viable cell count technique - clinical implications. $f \mathrm{Med}$ Microbiol 1994; 40: 435-9.

31 Nagata $K$, Satoh $H$, Iwahi T, Shimoyama T, Tamura T. Potent inhibitory action of the gastric proton pump inhibitor lansoprazole against urease activity of Helicobacter pylori: unique action selective for $\mathrm{H}$ pylori cells. Antimicrob Agents Chemother 1993; 37: 769-74. 